\title{
Field measurements of the backscattering coefficient in a cascading reservoir system: first results from Nova Avanhandava and Barra Bonita Reservoirs (São Paulo, Brazil)
}

Enner Alcântara, Fernanda Watanabe, Thanan Rodrigues, Nariane Bernardo, Luiz Rotta, Alisson Carmo, Marcelo Curtarelli \& Nilton Imai

To cite this article: Enner Alcântara, Fernanda Watanabe, Thanan Rodrigues, Nariane Bernardo, Luiz Rotta, Alisson Carmo, Marcelo Curtarelli \& Nilton Imai (2016) Field measurements of the backscattering coefficient in a cascading reservoir system: first results from Nova Avanhandava and Barra Bonita Reservoirs (São Paulo, Brazil), Remote Sensing Letters, 7:5, 417-426, DOI: 10.1080/2150704X.2016.1145361

To link to this article: https://doi.org/10.1080/2150704X.2016.1145361

Published online: 18 Feb 2016.

Submit your article to this journal $\sqsubset$

Џll Article views: 119

View Crossmark data [־

Citing articles: 10 View citing articles $[7$ 


\title{
Field measurements of the backscattering coefficient in a cascading reservoir system: first results from Nova Avanhandava and Barra Bonita Reservoirs (São Paulo, Brazil)
}

\author{
Enner Alcântara (10 ${ }^{a}$, Fernanda Watanabe ${ }^{a}$, Thanan Rodrigues ${ }^{a}$, Nariane Bernardo ${ }^{a}$, \\ Luiz Rotta ${ }^{\mathrm{a}}$, Alisson Carmo ${ }^{\mathrm{a}}$, Marcelo Curtarelli ${ }^{\mathrm{b}}$ and Nilton Imai ${ }^{\mathrm{a}}$
}

aSão Paulo State University, Unesp, Department of Cartography, Presidente Prudente, Brazil; ' ${ }^{\text {National }}$ Institute for Space Research - INPE, Remote Sensing Division, São José dos Campos, Brazil

\begin{abstract}
In this study, a data set of total suspended matter (TSM), chlorophyll- $a(\mathrm{Chl}-a)$, total backscattering coefficient $\left(b_{\mathrm{b}}\right)$ and the remote sensing reflectance $\left(R_{\mathrm{rs}}\right)$ were measured in the euphotic zone of two hydroelectric reservoirs at 71 stations during field surveys in the wet and dry seasons. These two reservoirs are located in a cascading system in Tietê River, São Paulo State, Brazil. The limnological and optical data were interpolated using the ordinary kriging technique to map their spatial distribution. The differences in TSM, Chl- $a$ and in $b_{\mathrm{b}}$ in space and time were investigated. The profiling data from $b_{\mathrm{b}}$ were analysed. All these data were used to explain the resulting $R_{\mathrm{rs}}$ spectra in these two reservoirs. For both reservoirs, the inorganic fraction of TSM was responsible for the $b_{\mathrm{b}}$ variability and therefore modulates the $R_{\mathrm{rs}}$ spectra. The seasonally difference in the optical data will help to understand how the inherent optical properties and the apparent optical properties changes in a cascading reservoir system.
\end{abstract}

\section{ARTICLE HISTORY}

Received 3 December 2015 Accepted 17 January 2016

\section{Introduction}

The backscattering coefficient refers to the portion of the scattering $(b)$ of electromagnetic radiation in the backward direction that is deflected through a scattering angle higher than $90^{\circ}$ and depends on the number, index of refraction, size and shape of the particles in water (Kirk 1994). It is defined mathematically as:

$$
b_{\mathrm{b}}=2 \pi \int_{90^{\circ}}^{180^{\circ}} \beta(\theta) \sin \theta \mathrm{d} \theta
$$

where $\beta(\theta)$ is the volume scattering function of the target volume, or the angular distribution of single-event scattering around the direction of a parallel incident beam and $\theta$ is the angle between the initial direction of light propagation and that to which the light is scattered irrespective of azimuth.

The total backscattering coefficient is composed by the contributions of the water and particulate components, including inorganic and organic matter. The $b_{\mathrm{b}}$ is of 
primary importance for remote sensing of water colour, as the radiometric signal recorded by a sensor onboard an aircraft or a satellite is directly proportional to its intensity (Loisel et al. 2007).

The research performed so far on the $b_{\mathrm{b}}$ properties of inland waters, especially in Brazilian hydroelectric reservoirs, is incipient and does not represent the $b_{\mathrm{b}}$ in the cascading systems. Hence to our knowledge, it is the first time that this type of research was conducted to study the influence of a cascading system configuration on the $b_{\mathrm{b}}$ distribution. The main objective of this article was to investigate the $b_{\mathrm{b}}$ variability due to the cascading system configuration.

\section{Materials and methods}

\subsection{Study area}

The Barra Bonita (BB) and Nova Avanhandava (Nav) reservoirs (Figure 1) are placed in the middle and lower courses of the Tietê River, São Paulo State, respectively. The BB reservoir $\left(22^{\circ} 31^{\prime} 10^{\prime \prime} \mathrm{S}, 48^{\circ} 32^{\prime} 3^{\prime \prime} \mathrm{W}\right)$ is a storage system and began its operation in 1963 flooding an area of $310 \mathrm{~km}^{2}$, with $480 \mathrm{~m}$ of dam length and 90.3 days of average residence time (Soares and Mozeto 2006), being formed from the damming of Tietê and Piracicaba Rivers. Nova Avanhandava $\left(21^{\circ} 7^{\prime} 1^{\prime \prime} \mathrm{S}, 50^{\circ} 12^{\prime} 6^{\prime \prime} \mathrm{W}\right)$ is a run-of-river reservoir and was created in 1982,
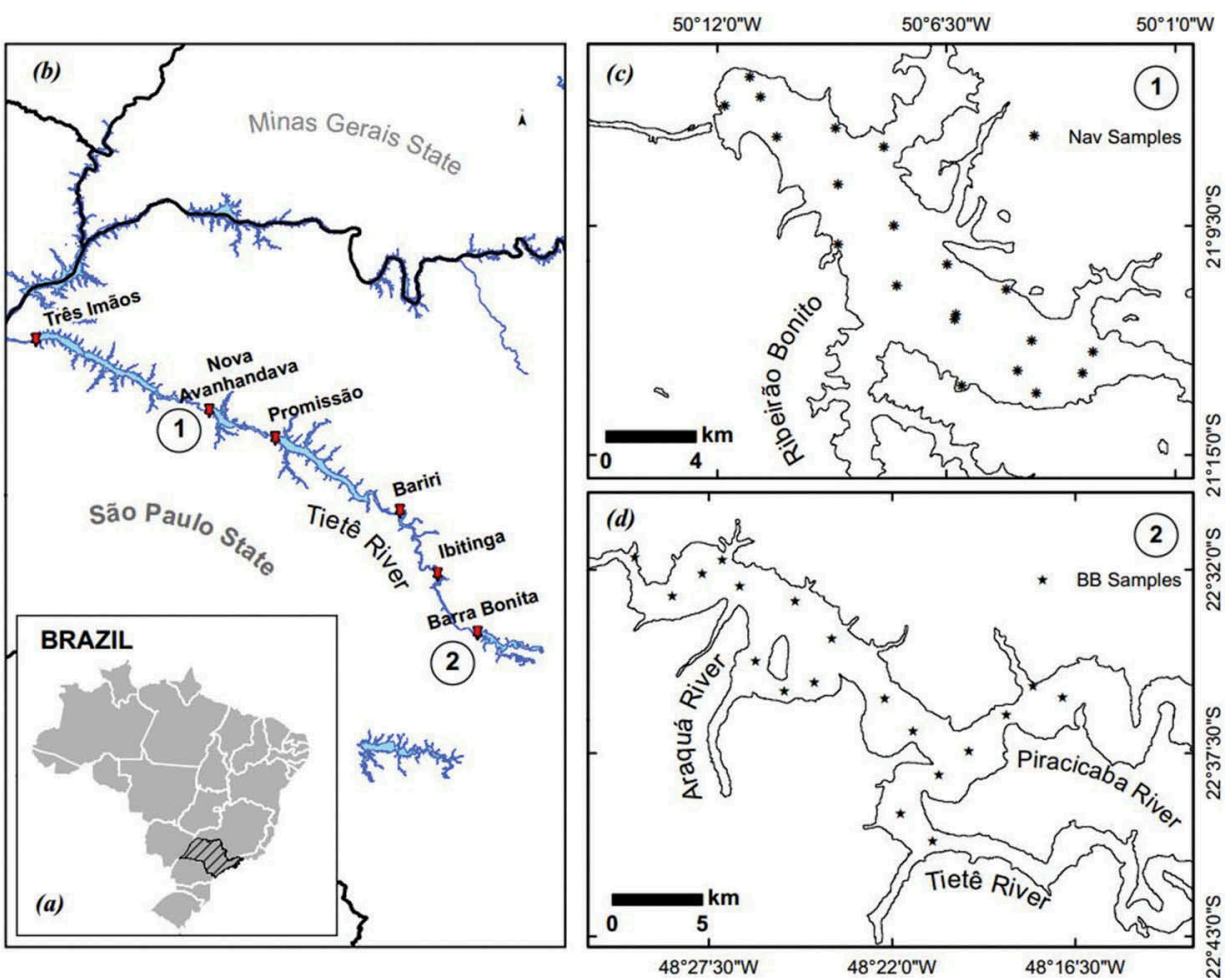

Figure 1. Study area: (a) location of São Paulo State in Brazil, (b) Tietê River and the reservoirs location, (c) samples location in Nav and (d) in BB reservoirs. The numbers 1 and 2 represent the location of Nav and BB reservoirs, respectively. 
flooding an area of $210 \mathrm{~km}^{2}$ (at its maximum quota), with a dam length of 2,038 $\mathrm{m}$ and mean residence time of the water around 46 days (Barbosa et al. 1999).

According to Padisák et al. (2000), this reservoir cascade plays an important role not only in providing services but also function as effective storing agents of considerable loads of nutrients, particularly at the upper-middle Tietê, contributing to the better water quality downstream of the cascade. In BB reservoir, unicellular centric diatoms dominated (38\% of biomass) with a considerable Microsystis (34\%) and in Nav reservoir the Cyanobacteria dominates (with $9 \%$ of Microcystis).

\subsection{Field campaign}

Two field campaigns were conducted in distinct seasons of the year for both BB and Nav reservoirs. In the BB reservoir, the first field survey was accomplished in 5-9 May 2014 (Austral Autumn to end of the wet season) and the second one was carried out in 13-16 October 2014 (Austral Spring to end of the dry season). In the Nav reservoir, the field campaigns occurred in two periods of the year, the first coinciding with the beginning of the dry season (28 April to 2 May) and the other coinciding with the end of the drought (23-26 September). A total of 71 in situ samples were collected from both reservoirs during the two field surveys.

\subsection{Water sampling processing}

Water samples were collected at each sampling spot and filtered through a glass fibre filter GF/F Whatman, $47 \mathrm{~mm}$ diameter and $0.7 \mu \mathrm{m}$ pore size, to estimate the $\mathrm{Chl}-a$ concentration ( $\mu \mathrm{g} . \mathrm{I}^{-1}$ ) in laboratory (Golterman 1975). To estimate total suspended matter (TSM) (mg. ${ }^{-1}$ ), water samples were also filtered through a glass fibre filter GF/F Whatman (47 $\mathrm{mm}$ diameter and $0.7 \mu \mathrm{m}$ pore size) and stored frozen in the dark (APHA 1998).

\subsection{Backscattering measurements}

During the first field survey, the total $b_{\mathrm{b}}$ coefficient was measured using a Hydroscat-6P instrument (HOBI Labs, Tucson, ZA, USA), and during the second field survey, the ECOBB9 (WET Labs, Philomath, OR, USA) was used. The Hydroscat-6P backscattering meter operates at six wavelength bands centred at 442, 470, 510, 589, 620 and $671 \mathrm{~nm}$ (Maffione and Dana 1997). On the other hand, ECO-BB9 acquires measurements at nine wavelengths centred at 412, 440, 488, 510, 532, 595, 650, 676 and 715 nm (WET Labs, 2013).

\subsection{Remote sensing reflectance}

The remote sensing reflectance $\left(R_{\mathrm{rs}}\right)$ curves were estimated from radiometric measurements taken between 10:00 and 14:00 h local time. At each sample station below and above, water radiometric measurements were taken using a hyperspectral radiometers RAMSES TriOS $^{\circledR}$ operating in the spectral range between 400 and $900 \mathrm{~nm}$ were acquired. The $R_{\mathrm{rs}}$ was calculated using the equation proposed by Mobley (1999) (Equation 2). 


$$
R_{\mathrm{rs}}=\frac{L_{\mathrm{w}}}{E_{\mathrm{s}}}=\frac{\left(L_{\mathrm{t}}-\rho L_{\mathrm{s}}\right)}{E_{\mathrm{s}}}
$$

where $L_{\mathrm{s}}\left(\mathrm{W} \mathrm{m} \mathrm{m}^{-2} \mathrm{sr}^{-1}\right)$ is the incident sky radiance; $L_{\mathrm{t}}\left(\mathrm{W} \mathrm{m} \mathrm{m}^{-2} \mathrm{sr}^{-1}\right)$ is the total radiance measured above surface and composed of the leaving-water radiance $\left(L_{\mathrm{w}}\right)$ and the portion of the $L_{\mathrm{s}}$ that is reflected by water surface $\left(L_{\mathrm{r}}\right) ; E_{\mathrm{s}}\left(\mathrm{W} \mathrm{m}^{-2}\right)$ is the incident sky irradiance; and $\rho$ is a reflectance factor related to direction, wavelength, wind speed, sensor field of view, and incident sky radiance distribution whose value adopted was 0.028 (Mobley 1999).

\subsection{Data interpolation}

The limnological data and the $b_{\mathrm{b}}$ were interpolated using the ordinary Kriging algorithm (Isaaks and Srivastava 1989). The semivariograms were fitted testing several theoretical models (spherical, exponential, Gaussian, linear and power) and using the weighted least square method. The theoretical model that gave minimum standard error was chosen for further analysis. In this case, the fitted model was based on the Gaussian model. The adjustment on the Gaussian model suggests the existence of smooth spatial variance pattern at the study site (Burrough and Mcdonnell 1998).

\section{Results and discussion}

\subsection{Descriptive statistics of limnological and optical properties}

The statistics of selected limnological and optical data in both reservoirs are shown in Table 1. The Chl- $a$ and TSM concentrations and $b_{\mathrm{b}}$ were higher during the second survey for both reservoirs.

\subsection{Limnological and backscattering coefficient variability}

The interpolated data for the first field survey can be accessed in Figure 2. The Chl- $a$ map for Nav and BB reservoir is shown in Figure 2(a) and (d), respectively. The Chl- $a$ in Nav reservoir is very low and can be considered as oligotrophic where the

Table 1 . Water quality parameters and the backscattering coefficient $\left(b_{\mathrm{b}}\right)$ descriptive statistics (SD is the standard deviation) for measurements taken from Nav and BB reservoirs.

\begin{tabular}{|c|c|c|c|c|c|c|c|}
\hline & & \multicolumn{2}{|c|}{ Chl- $a\left(\mu \mathrm{g} \mathrm{I}^{-1}\right)$} & \multicolumn{2}{|c|}{$\operatorname{TSM}\left(\mathrm{mg} \mathrm{I}^{-1}\right)$} & \multicolumn{2}{|c|}{$b_{\mathrm{b}}\left(\mathrm{m}^{-1}\right)$} \\
\hline & & $1^{\text {st }}$ survey & $2^{\text {nd }}$ survey & $1^{\text {st }}$ survey & $2^{\text {st }}$ survey & $1^{\text {st }}$ survey & $2^{\text {st }}$ survey \\
\hline \multirow[t]{4}{*}{ Nav } & Min. & 2.10 & 3.41 & 0.10 & 0.50 & 0.17 & 0.03 \\
\hline & Max. & 12.56 & 20.48 & 2.60 & 10.00 & 0.72 & 0.33 \\
\hline & Mean & 6.48 & 8.73 & 1.01 & 1.45 & 0.33 & 0.05 \\
\hline & SD & 2.52 & 4.17 & 0.62 & 2.03 & 0.12 & 0.06 \\
\hline \multirow[t]{4}{*}{ BB } & Min. & 19.10 & 263.20 & 3.60 & 10.80 & 0.25 & 0.20 \\
\hline & Max. & 293.20 & 797.80 & 16.30 & 32.80 & 0.86 & 0.27 \\
\hline & Mean & 124.70 & 428.70 & 7.20 & 20.80 & 0.48 & 0.24 \\
\hline & SD & 71.00 & 154.50 & 3.30 & 4.90 & 0.16 & 0.01 \\
\hline
\end{tabular}

Notes: The $b_{\mathrm{b}}$ values were measured at $442 \mathrm{~nm}$ for the first survey and at $440 \mathrm{~nm}$ for the second survey. These wavelengths were selected because they are widely accepted and used as reference to study the optically active components present into the water. 


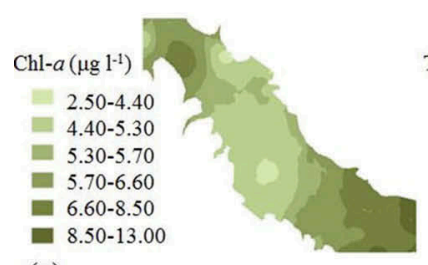

(a)

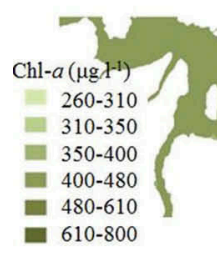

(d)

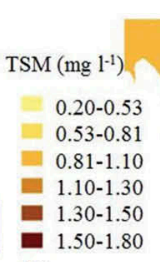

(b)

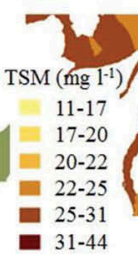

(e)

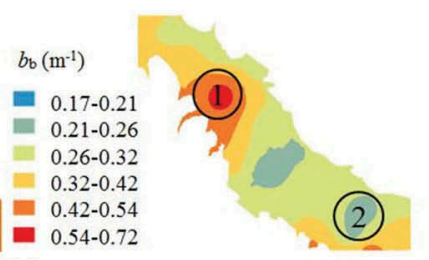

(c)
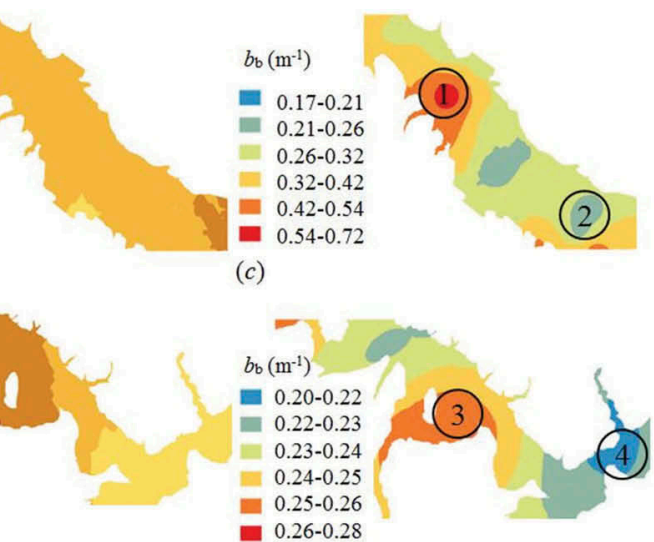

(f)

Figure 2. Interpolated data using ordinary kriging: (a) chlorophyll-a, (b) total suspended matter, (c) backscattering coefficient at $442 \mathrm{~nm}$ for Nova Avanhandava reservoir and (d) chlorophyll-a, (e) total suspended matter, (f) backscattering coefficient at $442 \mathrm{~nm}$ for Barra Bonita reservoir. These data were obtained during the first field survey. The numbers 1, 2, 3 and 4 highlighted in the figures represent the location of high and low $b_{\mathrm{b}}$ values in each reservoir.

concentrations are up to $3.24 \mu \mathrm{g} \mathrm{I}^{-1}$, and mesotrophic where the concentrations are

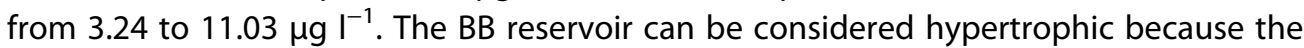
$\mathrm{Chl}-a$ concentrations are higher than $69.05 \mu \mathrm{g} \mathrm{I}^{-1}$. This classification was based on the classification adopted by the Environment Protection Agency in São Paulo State (CETESB, 2015).

The TSM concentrations were higher in the BB reservoir (Figure 2(c)) than in the Nav reservoir (Figure 2(e)), as expected from Table 1. In Nav reservoir, the TSM concentrations were higher at the entrance of the reservoir where the water comes from Promissão reservoir, decreasing downstream. For BB reservoir, the highest TSM concentrations were found downstream near the dam including the small rivers in the southeast region of the reservoir and decreasing upstream towards the Piracicaba and Tietê Rivers.

The $b_{\mathrm{b}}$ distribution for Nav and BB reservoirs was illustrated in Figure 2(c) and (f), respectively. In Nav reservoir, two spots were highlighted (see Figure 2 for location), the first (1) had the highest $b_{\mathrm{b}}$ values and the spot (2) the lowest one. The correlation between TSM and Chl- $a$ was 0.66 and the coefficient of determination $R^{2}$ was 0.44 , which means that about $44 \%$ of the TSM composition is dominated by Chl- $a$. In this case, the inorganic fraction of TSM is the main responsible for the $b_{\mathrm{b}}$ distribution shown in Figure 2(c).

In BB reservoir, two spots were also identified (see Figure 2 for location): the first (3) shows a coincidence between high $b_{\mathrm{b}}$ and TSM values and in spot (4) lowest $b_{\mathrm{b}}$ values, which coincided with the lowest TSM concentration. However, there was a correlation of 0.65 between the Chl- $a$ and TSM, with a $R^{2}$ of 0.43 and in the same fashion observed for Nav reservoir, the main responsible for $b_{\mathrm{b}}$ distribution was the inorganic fraction of TSM. In Figure 3 , it is possible to see the $b_{\mathrm{b}}$ vertical distribution for spots highlighted in Figure 2. Figure 3(a) and (b) is for Nav reservoir and Figure 3(c) and (d) is for BB reservoir. 

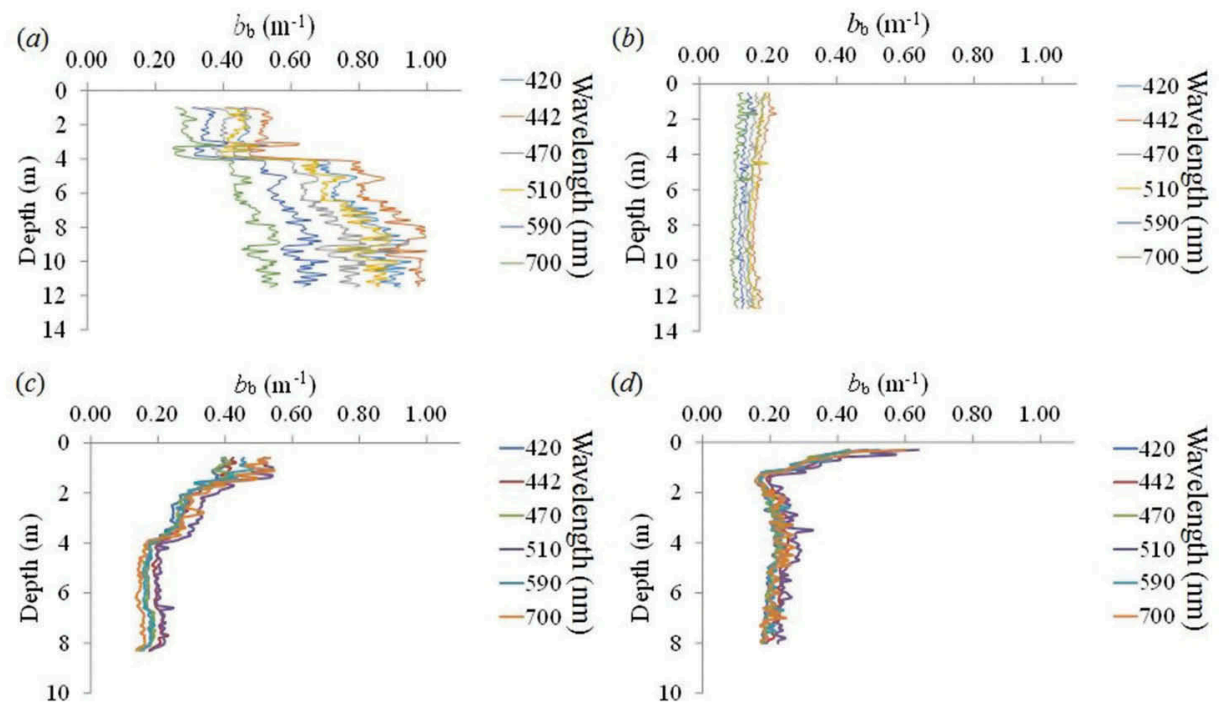

Figure 3. Vertical profiles of $b_{\mathrm{b}}$ for Nova Avanhandava reservoir (a) and (b) represent the spots 1 and 2, respectively, and for Barra Bonita reservoir (c) and (d) represent the spots 3 and 4, respectively. These data were obtained during the first field survey.

Overall, spot 1 showed more variability of $b_{\mathrm{b}}$ in depth than the others spots (Figure 3(a)) and also showed that the highest $b_{\mathrm{b}}$ values were observed at $442 \mathrm{~nm}$ and the lowest at $700 \mathrm{~nm}$.

For the second field survey, during the rainy season, the spatial patterns changed if compared with the first field survey during the dry season (Figure 4). Over again, the Chl- $a$ concentrations were higher for BB reservoir (Figure 4(a)) than for Nav reservoir (Figure $4(\mathrm{~d})$ ). Using the Chl- $a$ concentrations, it is possible to classify some parts as mesotrophic and others as eutrophic for Nav reservoir and as eutrophic and hypertrophic for BB reservoir. The TSM concentration was also higher in BB (Figure 4(b)) than in Nav reservoir (Figure 4(e)). As same as for the first field survey, BB reservoir showed the highest TSM concentrations near the dam. In Nav reservoir, the highest TSM concentrations were located in south-west region of the reservoir.

The $b_{\mathrm{b}}$ map for Nav reservoir matches with TSM concentration (Figure 4(c)), since the highest $b_{\mathrm{b}}$ (highlighted as 1 ) and the lowest (highlighted as 2) were coincident with the high and low TSM values. The highlighted regions 1 and 2 were the same highlighted for $b_{\mathrm{b}}$ measured in the first field survey (see Figure 3(c)). The BB reservoir showed a more complex $b_{\mathrm{b}}$ distribution (Figure $4(\mathrm{f})$ ), but there were some coincidences with the $b_{\mathrm{b}}$ map from the first survey. In this case, the highest $b_{\mathrm{b}}$ values (spot 4) were obtained in $a$ region with a high $\mathrm{Chl}-a$ concentration and the lowest $b_{\mathrm{b}}$ values (spot 3 ) matched with a region of low concentration.

Analysing the profiling $b_{\mathrm{b}}$ data (Figure 5) by spots highlighted in Figure 4(c) and (f) we noticed that for Nav reservoir spot 1 (higher $b_{\mathrm{b}}$ values) was higher only for wavelengths at 412 and $440 \mathrm{~nm}$. At longer wavelengths, the $b_{\mathrm{b}}$ values decreased. In addition, we can see that there are slight changes with depth, and the only exception was at $440 \mathrm{~nm}$, with a little variability in the depth near $3 \mathrm{~m}$; this indicated that the water 


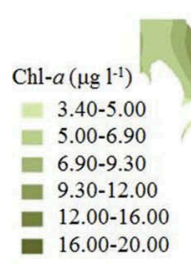

(a)

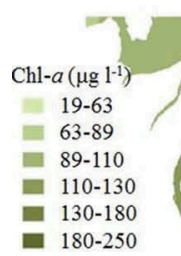

(d)

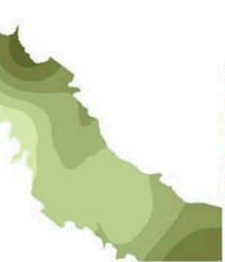

(b)

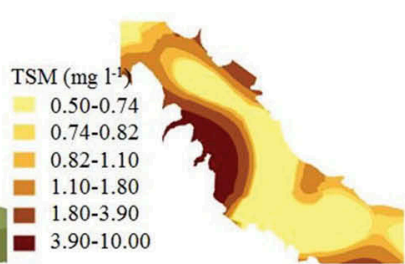

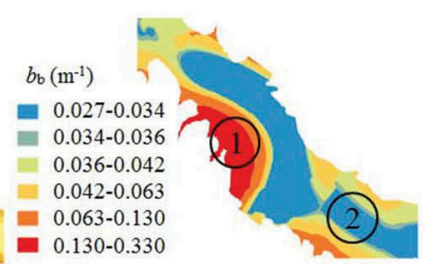

(c)

Figure 4. Interpolated data using ordinary kriging: (a) chlorophyll-a, (b) total suspended matter, (c) backscattering coefficient at $440 \mathrm{~nm}$ for Nova Avanhandava reservoir and (d) chlorophyll-a, (e) total suspended matter, (f) backscattering coefficient at $440 \mathrm{~nm}$ for Barra Bonita reservoir. These data were obtained during the second field survey.
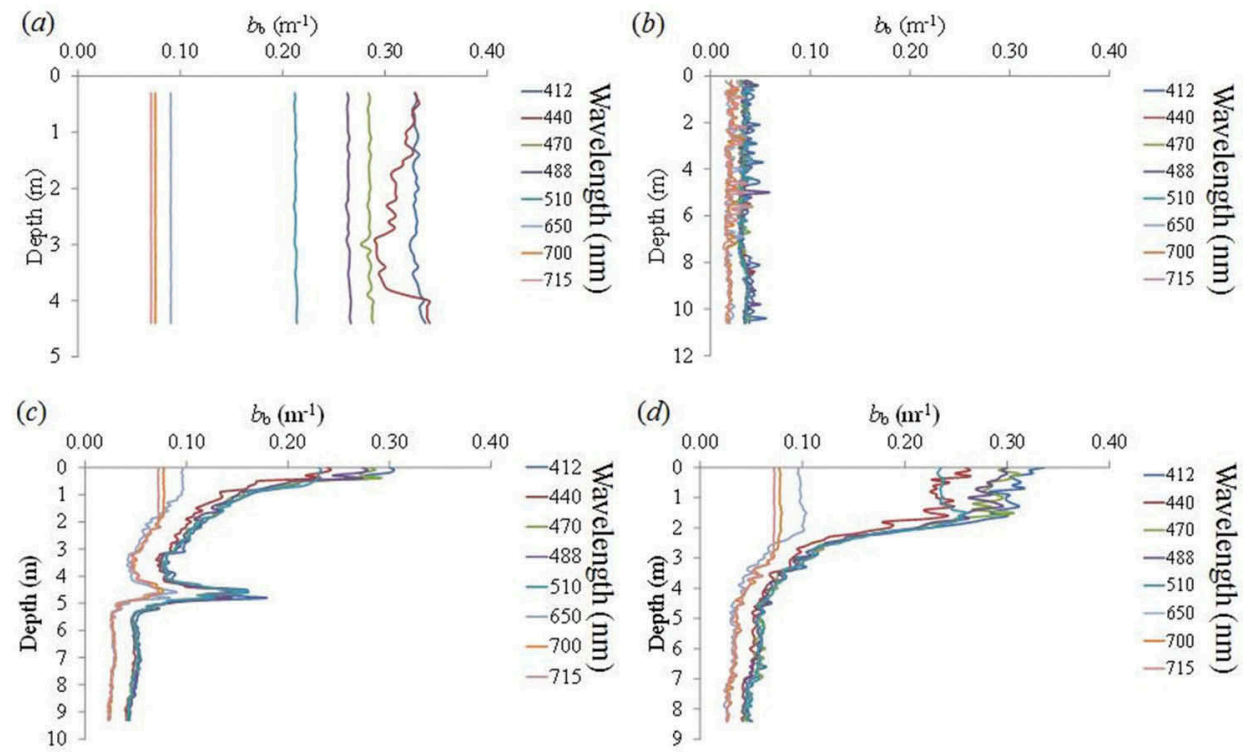

Figure 5. Vertical profiles of $b_{\mathrm{b}}$ for Nova Avanhandava reservoir (a) and (b) represent the spots 1 and 2, respectively, and for Barra Bonita reservoir (c) and (d) represent the spots 3 and 4, respectively. These data were obtained during the second field survey.

column was very clean. The lowest profiling $b_{\mathrm{b}}$ values were found for spot 2 (Figure 5(b)) in all wavelengths.

For BB reservoir, the spots 3 (Figure 5(c)) and 4 (Figure 5(d)) had such a stratification where the highest values were in the upper layer and the lowest in the lower layer. In these cases, higher wavelengths presented lower $b_{\mathrm{b}}$ values. The $b_{\mathrm{b}}$ values are higher 
than that observed for ocean waters in both reservoirs. Morel et al. (2007) studied hyperoligotrophic waters in South Pacific and obtained $b_{\mathrm{b}}$ values from 0.002 to 0.009 $\left(\mathrm{m}^{-1}\right)$ which are two orders of magnitude smaller than $b_{\mathrm{b}}$ values found in Nav and BB.

The spatial and profiling patterns will modulate the spectral response that consequently will be captured by a remote sensor. The following section showed and discussed the spectral shape for those four spots highlighted in Figures 2 and 4.

\subsection{Spectral reflectance}

Since the Nav reservoir is a very clear water, with low Chl- $a$ and TSM concentrations, then the main spectral behaviour showed higher reflectance at shorter wavelength and lower reflectance for longer wavelength (Figure 6(a) and (b)). These occur because there was more penetration of electromagnetic radiation in the water column for shorter wavelengths, and since the concentrations are very low, the radiation penetrates deeper (Rijkeboer, Dekker, and Gons 1997).

Solar energy penetration largely determines the biological productivity of aquatic ecosystems by controlling the heat budget, light availability for autotrophs at the base of the food web (Belzile et al. 2004). Since the Nav reservoir has low TSM concentrations, the backscattering at longer wavelengths will be low as the reflectance. There was a shift of the red wavelength towards longer wavelengths due to the increase in the TSM concentration. This is especially true for the second field survey in Nav reservoir (Figure 6 (b)) where the TSM concentration was 3.8 times higher than the TSM concentration measured in the first field survey.
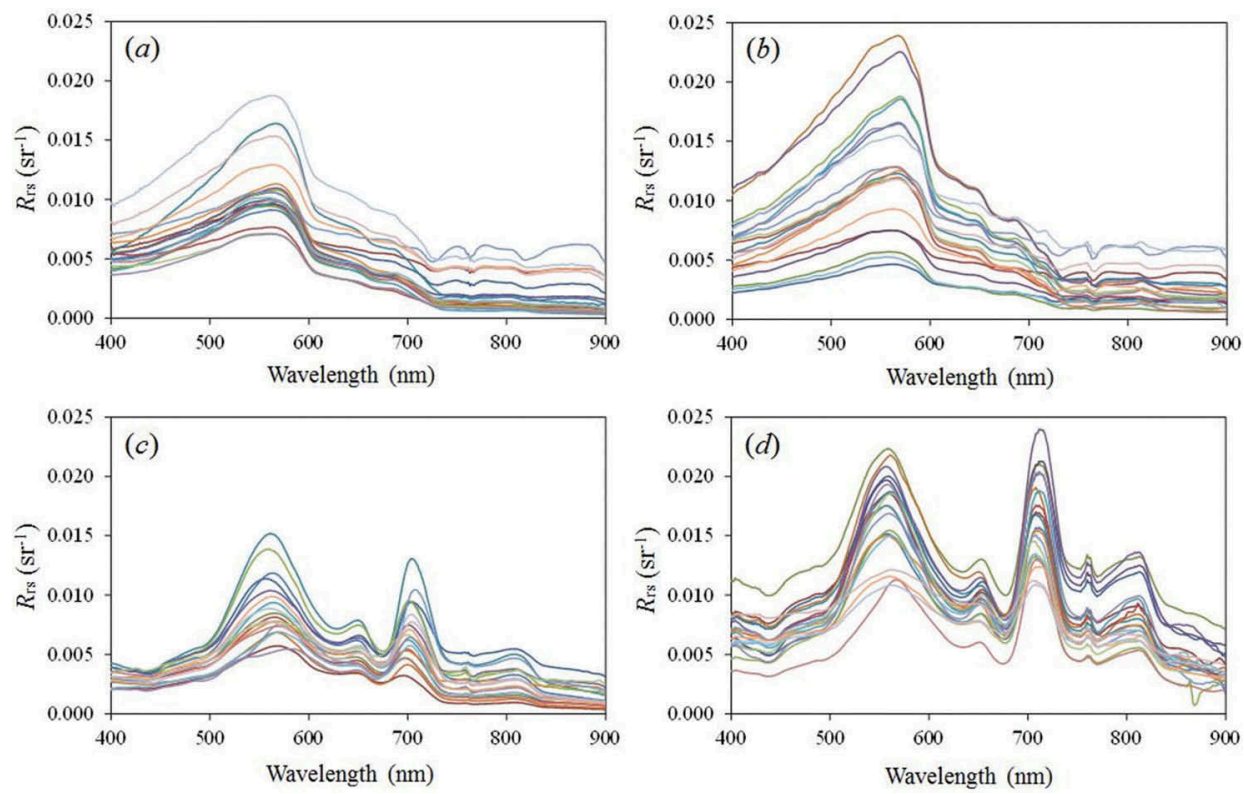

Figure 6. $R_{\mathrm{rs}}\left(\mathrm{sr}^{-1}\right)$ calculated for Nav and $\mathrm{BB}$ reservoirs, during the first $(\mathrm{a}, \mathrm{c})$ and second field survey $(b, d)$, respectively. 
In $\mathrm{BB}$ reservoir, the absorption feature of the phycocyanin pigment at approximately $620 \mathrm{~nm}$ was associated with the presence of cyanobacteria in both field surveys (Figure 6(c) and (d)). In addition, there were a higher absorption at about $680 \mathrm{~nm}$ and a reflectance at approximately $710 \mathrm{~nm}$ that can be associated with the Chl- $a$ pigment (Watanabe et al. 2015). Another reflection feature was observed at $810 \mathrm{~nm}$ associated with both Chl- $a$ and organic matter (Rundquist et al. 1996), which results from the low absorption of pure water at this wavelength. The increase of reflectance in longer wavelength was indicative of increases in TSM concentration. The Chl-a concentration in BB reservoir during the second survey was 2.8 times lower than in the first survey and this explained why the absorption for pigments was more evident during the second survey.

In the rainy season, the reflectance of both Nav and BB reservoirs was lower than that measured during the dry season. The run-off generated due to the rain carried an amount of particles for the water surface, then the reflectance at shorter wavelengths decreased. The rain also helped in mixing and oxygenating the water column, which prevented the phytoplankton blooms. During the dry season, the suspended matter was not on the surface anymore because they settled on the bottom. The reflectance at shorter wavelengths will increase, and due to the weather with hot air, lower wind speed the phytoplankton blooms took place.

\section{Conclusion}

The cascading reservoir configuration functions as a filter that improves the water quality. On the other hand, it contributes to decrease the optically active compounds concentrations and the values of $b_{\mathrm{b}}$. This filtration also alters the water reflectance. There was a seasonal influence on both limnological and optical data that can be explained by the influence of the rain (due to run-off). At the end of these cascading reservoirs, the spectra had a shape of very clear water, without some characteristics of phytoplankton-laden water.

\section{Disclosure statement}

No potential conflict of interest was reported by the authors.

\section{Funding}

The authors thank São Paulo Research Foundation - FAPESP [Project number: 2012/19821-1] and National Counsel of Technological and Scientific Development - CNPq [Projects numbers: 400881/ 2013-6 and 472131/2012-5] for financial support.

\section{ORCID}

Enner Alcântara (D) http://orcid.org/0000-0002-7777-2119 


\section{References}

APHA. 1998. Standard Methods for the Examination of Water and Wastewater. 20th ed. Washington, DC: American Public Health Association (APHA), American Water Works Association (AWWA), Water Environmental Federation (WEF).

Barbosa, F. A. R., J. Padisák, E. L. G. Espíndola, G. Borics, and O. Rocha. 1999. "The Cascading Reservoir Continuum Concept (CRCC) and Its Application to the River Tietê-Basin, São Paulo State, Brazil." In Theoretical Reservoir Ecology and Its Applications. International Institute of Ecology, eds. J. G. Tundisi, and M. Straskraba, 425-437. São Carlos: Academy of Sciences and Backhuys Publishers.

Belzile, C., W. F. Vincent, C. Howard-Williams, I. Hawes, M. R. James, M. Kumagai, and C. Roesler. 2004. "Relationships between Spectral Optical Properties and Optically Active Substances in a Clear Oligotrophic Lake." Water Resources Research 40 (12): n/a-n/a. doi:10.1029/2004WR003090.

Burrough, P. A., and R. A. Mcdonnell. 1998. Principles of Geographical Information Systems, 333. New York: Oxford University Press.

CETESB (Companhia Ambiental do Estado de São Paulo). Águas superficiais. CETESB: São Paulo, Brasil. 2015. Accessed 23 April 2015. http://www.cetesb.sp.gov.br/agua/aguas-superficiais/35publicacoes-/-relatorios

Golterman, H. L. 1975. Developments in Water Science 2. Physiological limnology: an approach to the physiology of lake ecosystems. Amsterdam, Netherlands: Elsevier.

Isaaks, E. H., and M. R. Srivastava. 1989. An Introduction to Applied Geostatistics, 561 p. New York: Oxford University Press.

Kirk, J. T. O. 1994. Light and Photosynthesis in Aquatic Ecosystems. 2nd ed. Cambridge: Cambridge University Press.

Loisel, H., X. Mériaux, J.-F. Berthon, and A. Poteau. 2007. "Investigation of the Optical Backscattering to Scattering Ratio of Marine Particles in Relation to Their Biogeochemical Composition in the Eastern English Channel and Southern North Sea." Limnology and Oceanography 52: 739-752. doi:10.4319/lo.2007.52.2.0739.

Maffione, R. A., and D. R. Dana. 1997. "Instruments and Methods for Measuring the BackwardScattering Coefficient of Ocean Waters." Applied Optics 36: 6057-6067. doi:10.1364/AO.36.006057.

Mobley, C. D. 1999. "Estimation of the Remote-Sensing Reflectance from Above-Surface Measurements." Applied Optics 38: 7442-7455. doi:10.1364/AO.38.007442.

Morel, A., B. Gentili, H. Claustre, M. Babin, A. Bricaud, J. Ras, and T. Fanny. 2007. "Optical Properties of the "Clearest" Natural Waters." Limnology and Oceanography 52: 217-229. doi:10.4319/ lo.2007.52.1.0217.

Padisák, J., F. A. R. Barbosa, G. Borbély, G. Borics, I. Chorus, E. L. G. Espíndola, R. Heinze, O. Rocha, A. K. Törökné, and G. Vasas. 2000. "Phytoplankton Composition, Biodiversity and a Pilot Survey of Toxic Cyanoprokaryotes in a Large Cascading Reservoir System (Tietê Basin, Brazil)." Verh. Internat. Verein. Limnol 27: 2734-2742.

Rijkeboer, M., A. G. Dekker, and H. J. Gons. 1997. "Subsurface Irradiance Reflectance Spectra of Inland Waters Differing in Morphometry and Hydrology." Aquatic Ecology 31: 313-323. doi:10.1023/A:1009916501492.

Rundquist, D. C., L. Han, J. F. Schalles, and J. S. Peake. 1996. "Remote Measurement of Algal Chlorophyll in Surface Waters: The Case for the First Derivative of Reflectance near $690 \mathrm{Nm} . "$ Photogrammetric Engineering \& Remote Sensing 62: 195-200.

Soares, A., and A. A. Mozeto. 2006. "Water Quality in the Tietê River Reservoirs (Billings, Barra Bonita, Bariri E Promissão, SP- Brazil) and Nutrient Fluxes across the Sediment-Water Interface (Barra Bonita)." Acta Limnologica Brasiliensia 18: 247-266.

Watanabe, F., E. H. Alcântara, T. Rodrigues, N. N. Imai, C. Barbosa, and L. Rotta. 2015. "Estimation of Chlorophyll-a Concentration and the Trophic State of the Barra Bonita Hydroelectric Reservoir Using OLI/Landsat-8 Images." International Journal of Environmental Research and Public Health 12: 10391-10417. doi:10.3390/ijerph120910391.

WET Labs, Inc., 2013. Scattering Meter (ECO-BB9) User's Guide. Revision L. http://www.wetlabs.com/ manuals 